\title{
Endodontics
}

\section{Dissolving efficacy of some organic solvents on gutta-percha}

\author{
Eficácia dissolvente de alguns solventes \\ orgânicos sobre a guta-percha
}

\author{
Bianca Silva Magalhães(a) \\ Julia Elis Johann ${ }^{(a)}$ \\ Rafael Guerra Lund(b) \\ Josué Martos ${ }^{(c)}$ \\ Francisco Augusto Burkert Del Pino(d)
}

(a) Undergraduate Students; (b)Master's Degree Student, Department of Restorative Dentistry; (c) Professor, Department of Clinics - School of Dentistry, Federal University of Pelotas.

(d) Professor, Department of Biochemistry, Chemistry Institute, Federal University of Pelotas.

\begin{abstract}
The aim of this study was to evaluate the solubility of gutta-percha in four organic solvents used in endodontics. The solubility of gutta-percha (Dentsply) was assessed in xylol, orange oil, eucalyptol, chloroform and distilled water. A hundred and fifty samples of gutta-percha were prepared using a standardized stainless steel mould and divided into five groups for immersion in the different solvents tested and in distilled water (control group) for 2, 5 and 10 minutes. The means of gutta-percha dissolution in the solvents were obtained by the difference between the pre-immersion original weight and the post-immersion weight in a digital analytical scale (Gehaka-AG2000). Data were statistically analyzed by Analysis of Variance (ANOVA) and multiple comparisons with Scheffe's test $(\mathrm{p}<0.05)$. The best solvency capacity was obtained with xylol. Chloroform, orange oil and eucalyptol presented similar results, and distilled water did not promote alterations in the gutta-percha.
\end{abstract}

Descriptors: Endodontics; Retreatment; Solubility; Gutta-percha; Solvents.

Resumo: O presente estudo avaliou a solubilidade da guta-percha em quatro solventes orgânicos empregados em endodontia. A solubilidade da guta-percha (Dentsply) foi testada em xilol, óleo de laranja, eucaliptol, clorofórmio e água destilada. Foram preparadas cento e cinqüenta amostras de guta-percha por meio de uma matriz metálica que foram divididas em cinco grupos para imersão nos diferentes solventes a serem testados e na água destilada (grupo controle) durante 2, 5 e 10 minutos. As médias da dissolução da gutapercha nos diferentes solventes foram obtidas pela diferença entre o peso inicial pré-imersão e o peso pós-imersão através de uma balança analítica digital (Gehaka - AG2000). Os dados foram analisados estatisticamente através da análise de variância (ANOVA) e comparações múltiplas com teste de Scheffe's $(p<0,05)$. A melhor capacidade de solvência foi obtida com o xilol. Clorofórmio, óleo de laranja e eucaliptol apresentaram resultados semelhantes, e a água destilada não promoveu alterações na guta-percha.

Descritores: Endodontia; Retratamento; Solubilidade; Guta-percha; Solventes.

\author{
Corresponding author: \\ Josué Martos \\ Departamento de Clínica \\ Faculdade de Odontologia \\ Universidade Federal de Pelotas \\ Rua Gonçalves Chaves, 457 \\ Pelotas - RS - Brazil \\ CEP: 96015-560 \\ E-mail: josue.sul@terra.com.br
}

Received for publication on Sep 12, 2006 Sent for alterations on Dec 01, 2006 Accepted for publication on Jan 19, 2007 


\section{Introduction}

Gutta-percha is the most frequently used filling material for root canal obturation. This thermoplastic material fulfills the main requisites for root canal filling, one of which is to be an easily removable material in cases of endodontic retreatment. The methods used to perform it are mechanical, thermal, chemical, or even an association of them, and also special instruments such as ultrasound instruments can be used. ${ }^{1,2,7,9}$

Most often Gutta-percha cones are composed of a vegetable resin, which lends its name to the product, and they are softened by chemical solvents. ${ }^{11}$

Among the organic solvents more frequently used in endodontics, prominent are: chloroform, xylol, halothane, eucalyptol, turpentine (terebintine) and orange oil. ${ }^{1,4,5,6,11,15,17}$

Gutta-percha can be easily removed with the use of an organic solvent or heated instrument. However, these substances seem to show variable degrees of success regarding dissolution and removal of this material from the root canal.

Organic solvents have been used for a long time as an auxiliary or principal method of gutta-percha removal, being the more effective chemical substances to dissolve the filling endodontic material. Chloroform and xylene are the two most commonly used solvents, but the U.S. Food and Drug Administration prohibit chloroform because of its potential carcinogenicity. Xylene is available nowadays for clinical use, and it is not considered a carcinogen, but is very toxic to tissues. . $^{3,13,18}$

Gutta-percha is also soluble to essential oils. Some of them have been reported as safe and useful for this purpose, like eucalyptus (eucalyptol) and pine tree (turpentine) essential oils. ${ }^{14}$ According to Pécora et al. ${ }^{10}$ (1992), orange oil acts on gutta-percha in the same way that xylol does, without presenting any deleterious effect of that.

Nowadays, the procedures of retreatment have become even more important in endodontics, replacing traditional surgical methods. Different solvents have been largely used to empty the root canal. Their properties should be taken in consideration regarding effectiveness in the dissolution of the endodontic filling material.
The purpose of this study was to comparatively evaluate the dissolution efficiency of different guttapercha solvents at three time intervals.

\section{Material and Methods}

One commercial brand of gutta-percha (Dentsply, Petrópolis, RJ, Brazil) was included in this study. Eucalyptol (Odontopharma, Porto Alegre, RS, Brazil), xylol (Labsinth Ltda., Diadema, SP, Brazil), chloroform (Labsinth Ltda., Diadema, SP, Brazil) and orange oil (Dierberger, Pelotas, RS, Brazil) were tested as solvents. Distilled water obtained from a Milli-Q water system (Millipore Corporation, Bedford, MA, USA) was used as a no solvent control.

Standardized stainless steel moulds with $8 \mathrm{~mm}$ in diameter and $2 \mathrm{~mm}$ in height were used for sample preparation. Master cones of gutta-percha were heated and condensed into sample moulds and left to set at room temperature for $48 \mathrm{~h}$. Excess material was then trimmed to the surface level of the mould with a scalpel.

One hundred and fifty shaped discs of gutta-percha were prepared and divided into five groups of thirty, for immersion in xylol, orange oil, eucalyptol, chloroform or distilled water and were further divided into three equal subgroups $(\mathrm{n}=10)$ for 2,5 and $10 \mathrm{~min}$.

Samples were weighed in a digital analytical scale (Gehaka AG 2000, Gehaka Ltda., São Paulo, SP, Brazil) in grams and recorded to four decimal places in triplicate. Gutta-percha discs were immersed in $20 \mathrm{ml}$ of solvent at room temperature in an amber glass bottle (Corning Inc., Canton, NY, USA) with a screw cap so that both surfaces of each sample were freely accessible to the solvent.

Samples were removed from the glass vial after the specified immersion period and washed in $100 \mathrm{ml}$ of double-distilled water and allowed to dry for $24 \mathrm{~h}$ at $37 \pm 1^{\circ} \mathrm{C}$ in an oven and kept in a dissecator. The extent of gutta-percha dissolution removed from the specimen was calculated from the difference between the original weight of gutta-percha and its final weight using the following equation:

$$
M=M_{2}-M_{1},
$$


where:

$M_{2}=$ post-immersion weight;

$M_{1}=$ pre-immersion weight.

Means and standard deviations of percentage loss of weight were calculated at each time interval for each group of specimens. The values were compared by statistical parametric tests using the software SPSS 8.0 (SPSS Inc., Chicago, IL, USA). The difference in dissolution of gutta-percha along the different times tested was calculated by Two-Way ANOVA. Multiple comparisons with Scheffé's test were further performed to compare the effect of the different solvents in different times with the value of statistical significance set at 0.05 .

\section{Results}

Dissolution means and standard deviations recorded for the different solvents are summarized in Table 1.

The weight loss of gutta-percha as a function of time is presented in Graph 1. For the first batch of samples with immersion time 2 minutes, all solvents presented similar effects $(F=2.250, \mathrm{p}=0.081)$, ex-

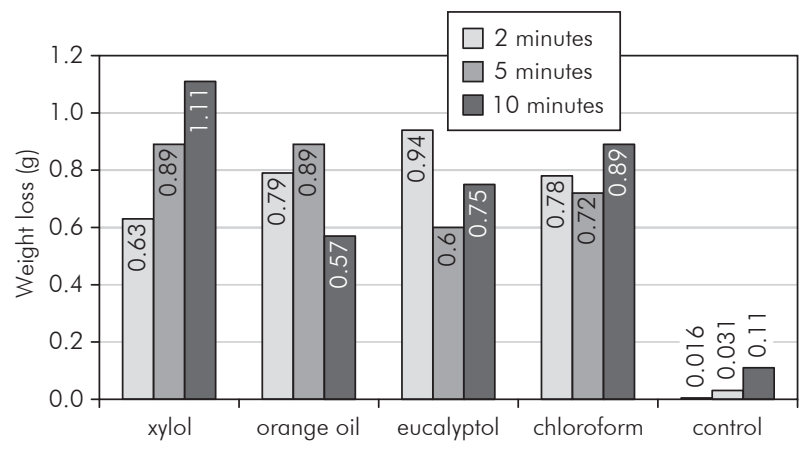

Graph 1 - Time-dependent solubility effect of solvents on gutta-percha. Solubility is expressed as weight loss in grams. cept the control group.

For 10-minutes immersion time, Xylol displayed a markedly superior ability in dissolving gutta-percha in comparison to the others solvents $(\mathrm{p}<0.05)$. In the distilled water control group, no gutta-percha discs were dissolved.

Chloroform, orange oil and eucalyptol did not show statistically significant differences at 5 and 10 minutes ( $\mathrm{p}>0.05$ ).

The best solvency capacity was obtained with xylol, while chloroform, eucalyptol and orange oil showed similar solvent effects, and distilled water did not promote alterations in the guta-percha.

\section{Discussion}

Clinical trials standardization concerning solubility generally follows the ISO normative. However, there is no such normative to evaluate the effect of endodontic solvents on gutta-percha materials.

Considering the great perspective of success in endodontic reinterventions, retreatment becomes a conservative clinical conduct in comparison with some more radical procedures such as periapical surgeries. The removal of the endodontic filling material from the root canal is a requirement for retreatment.

Gutta-percha in conjunction with a variety of root canal sealers is the most commonly used root canal filling material. Several methods to remove the filling material are available, including the use of solvents, the thermal method and mechanical instrumentation, individually or in combination of the three. ${ }^{1,2,7,9}$

Gutta-percha can be removed without great difficulty with the use of an organic solvent or heated instruments. ${ }^{2,9}$ Our results showed that xylol is the most effective for gutta-percha dissolution compared

Table 1 - Means and standard deviations of gutta-percha solubility in solvents during immersion times. Solubility is expressed as weight loss in grams.

\begin{tabular}{c|c|c|c|c|c}
\hline & Xylol & Orange oil & Eucalyptol & Chloroform & MiliQ $^{\mathrm{TM}}$ water \\
\hline 2 minutes & $0.6380 \pm 0.69^{a}$ & $0.7941 \pm 0.66^{\mathrm{a}}$ & $0.9438 \pm 0.69^{\mathrm{a}}$ & $0.7869 \pm 0.44^{\mathrm{a}}$ & $0.0168 \pm 0.004^{\mathrm{b}}$ \\
\hline 5 minutes & $0.8984 \pm 0.78^{\mathrm{a}}$ & $0.8907 \pm 0.61^{\mathrm{ab}}$ & $0.6099 \pm 0.53^{\mathrm{ab}}$ & $0.7282 \pm 0.58^{\mathrm{ab}}$ & $0.0316 \pm 0.027^{\mathrm{c}}$ \\
\hline 10 minutes & $1.1105 \pm 0.62^{\mathrm{a}}$ & $0.5794 \pm 0.43^{\mathrm{ab}}$ & $0.7573 \pm 0.43^{\mathrm{ab}}$ & $0.8941 \pm 0.78^{\mathrm{ab}}$ & $0.1196 \pm 0.18^{\mathrm{c}}$ \\
\hline
\end{tabular}

Means followed by the same superscript letters in the column indicate no statistically significant differences $(P>0.05)$. 
to the other tested solvents. Eucalyptol, chloroform and orange oil showed similar solvent effects, while distilled water showed no dissolution ability.

Chemical methods for gutta-percha removal or decontamination ${ }^{12}$ have been used for a long time. Nevertheless, substances that are the most effective solvents have the most potential toxicity. Several studies report that even substances which are used far from the periapex, such as in the pulp chamber, can reach the periapical tissues. ${ }^{16}$

Xylol and chloroform are classified among the solvents with major capacity of dissolution of guttapercha and also as those which present the most undesirable effects to the periapical tissues, ${ }^{13}$ as well as being considered potentially carcinogenic and neurotoxic. $^{18}$

In the present study, eucalyptus oil or eucalyptol and orange oil were statistically similar to chloroform ( $\mathrm{p}>0.05)$, in agreement with the study by Hunter et al. ${ }^{4}$ (1991) but differing from other investigations that observed significantly less dissolution efficiency. ${ }^{3,15,17}$

The use of essential oils in endodontics is growing because of their proved safety, biocompatibility and non-carcinogenicity. ${ }^{5,6}$ The results of this study indicate that both eucalyptol and orange oil are suitable as solvents, for dissolving or softening gutta-percha.

Essential oil extracted from the peel of sweet orange, Citrus aurantium, is easy to obtain and suitable for rapid opening of the root canal, mainly in zinc-oxide cement root fillings associated or not with gutta-percha cones. Orange oil is an excellent alternative solvent as compared to potentially toxic

\section{References}

1. Bueno CES, Valdrighi L. Efetividade de solventes e de técnicas na desobturação dos canais radiculares: estudo in vitro. Rev Bras Odontol. 1998;55(4):251-5.

2. Friedman S, Stabholz A, Tamse A. Endodontic retreatment - case selection and technique. 3. Retreatment techniques. J Endod. 1990;16(11):543-9.

3. Görduysus MÖ, Tasman F, Tuncer S, Etikan I. Solubilizing efficiency of different gutta-percha solvents: a comparative study. J Nihon Univ Sch Dent. 1997;39(3):133-5. solvents, being used either on eugenol zinc-oxide cement or to soften and dissolve gutta-percha. . $^{8,9,10,14}$

Eucalyptol (the main constituent of eucalyptus oil) exhibits antibacterial effects and anti-inflammatory properties, and its potential of dissolution of gutta-percha increases significantly when heated., ${ }^{9,11}$ If not heated, it dissolves the material more slowly.

Furthermore, after emptying the root canals, this solvent is easily removed by irrigation with tensio-active solutions such as lauril sodium sulphate or similar. ${ }^{10}$

Considering the existence of similarity in solvent capacity between essential oils and the other organic solvents investigated, we could clinically use eucalyptol and orange oil for a longer time. The uncontrollable miscibility and penetration depth of solutions like xylol and chloroform promote an uncontrolled field reaching the apical region and causing a chemical pericementitis.

The choice of an ideal solvent for endodontic retreatment requires the establishment of a balance between the level of clinical safety, the level of toxicity and aggression to the tissues, and the chemical capacity of dissolution.

\section{Conclusions}

Within the limitations of this in vitro study, we were able to conclude that:

1. Xylol presented a superior solvent effect.

2. Chloroform, orange oil and eucalyptol presented similar solvent effects.

3. We should limit the clinical use of solvents that present toxic and carcinogenic effects.

4. Hunter RK, Doblecki W, Pelleu GB. Halothane and eucalyptol as alternatives to chloroform for softening gutta-percha. $\mathrm{J}$ Endod. 1991;17(7):310-2.

5. Kaplowitz GJ. Evaluation of gutta-percha solvents. J Endod. 1990;16(11):539-40.

6. Kaplowitz GJ. Evaluation of the ability of essential oils to dissolve gutta-percha. J Endod. 1991;17(9):448-9.

7. Ladley RW, Campbell AD, Hicks ML, Li SH. Effectiveness of halothane used with ultrasonic or hand instrumenta- 
tion to remove gutta-percha from the root canal. J Endod. 1991;17(5):221-4.

8. Martos J, Gastal MT, Sommer L, Lund RGL, Del Pino FAB, Osinaga PWR. Dissolving efficacy of organic solvents on root canal sealers. Clin Oral Invest. 2006;10(1):50-4.

9. Oyama KON, Siqueira EL, Santos M. In vitro study of effect of solvent on root canal retreatment. Braz Dent J. 2002;13(3):208-11.

10. Pécora JD, Costa WF, Filho DS, Sarti SJ. Apresentação de um óleo essencial, obtido de Citrus aurantium, eficaz na desintegração do cimento de óxido de zinco-eugenol do interior do canal radicular. Odonto. 1992;1(5):130-2.

11. Pécora JD, Spanó JCE, Barbin EL. In vitro study on the softening of gutta-percha cones in endodontic retreatment. Braz Dent J. 1993;4(1):43-7.

12. Souza RE, Souza EA, Sousa-Neto MD, Pietro RC. In vitro evaluation of different chemical agents for the decontamination of gutta-percha cones. Pesqui Odontol Bras. 2003;17(1):75-7.
13. Spangberg L, Langeland K. Biologic effects of dental materials. 1. Toxicity of root canal filling materials on HeLa cells in vitro. Oral Surg Oral Med Oral Pathol. 1973;35(3):402-14.

14. Spanó JCE, Barbin EL, Bonini A, Pécora JD. Eficácia dos óleos essenciais na desobturação dos canais radiculares. ROBRAC. 1995;5(14):25-8.

15. Tamse A, Unger U, Metzger Z, Rosenberg M. Gutta-percha solvents - a comparative study. J Endod. 1986;12(8):337-9.

16. Walton RE. Intracanal medications. Dent Clin North Am. 1984;28(4):783-96.

17. Wennberg A, Orstavik D. Evaluation of alternatives to chloroform in endodontic practice. Endod Dent Traumatol. 1989;5(5):234-7.

18. Wourms DJ, Campbell AD, Hicks ML, Pelleu GB Jr. Alternative solvents to chloroform for gutta-percha removal. J Endod. 1990;16(5):224-6. 